\title{
$\beta$-Aminobutyric Acid-Induced Resistance Against Plant Pathogens
}

The potential of a plant to resist attack by a pathogen is enhanced after an initial inoculation with a necrotrophic pathogen. Not only the initially inoculated tissue, but also the remote organs such as leaves and roots, become resistant. Such immunization, named systemic acquired resistance (SAR), was first observed by Chester (4) with Tobacco mosaic virus (TMV) in tobacco and was further demonstrated by the pioneering work of Ross (50) and Kuc $(28,29)$. Efforts devoted to discovering the signal translocating during SAR revealed $(26,35,40)$ the central role of salicylic acid (SA) in activating the defense mechanisms leading to SAR. Functional analogs of SA, such as 2,6-dichloroisonicotinic acid (INA) or benzo[1,2,3] thiadiazole-7-carbothionic acid $S$-methyl ester (BTH or acibenzolar-Smethyl), were developed which activate the resistance mechanisms downstream of SA $(16,26,35,40,57)$. Since the observations of Chester, little attention was given to the role of induced resistance in general, and of amino acids in particular, in plant defense (29). Kuc et al. were the first to notice in 1957 (31) and 1959 (30) that Dphenylalanine, D-alanine, and DL-tryptophan injected into apple leaves increased resistance against scab without affecting the causal pathogen in vitro. As early as 1958, Van Andel (60) examined 50 amino acids for inducing resistance against Cladosporium cucumerinum in cucumber and found only D-serine, D-threonine, and L-threo- $\beta$-phenylserine highly active in vivo but not in vitro. Interestingly, she found no activity with DL- $\alpha$-aminobutyric (AABA), DL- $\beta$-aminobutyric (BABA), $\gamma$ aminobutyric (GABA), or their iso isomers (60).

In 1960, Oort and Van Andel first noted induced resistance to tomato late blight following BABA treatment (39). In 1963, two groups reported on the activity of aminobutrates. MacLennan et al. (34) showed that D-AABA and AIB (2-aminoisobutyric

Dr. Cohen's address is: Faculty of Life Sciences, Bar-Ilan University, Ramat-Gan 52900, Israel; E-mail: coheny@mail.biu.ac.il

Publication no. D-2002-0304-01F

(c) 2002 The American Phytopathological Society acid) were active in apple leaves against scab (but not L-AABA, BABA, or isoBABA). Papavizas and Davey (45) reported on the partial activity of AABA and high activity of BABA against Aphanomyces euteiches causing root rot in peas. They also showed high SAR activity with longer, straight-chain aminobutyrates such as DL- $\alpha$-aminovaleric (DL-norvaline, five carbons) and DL- $\alpha$-aminocaprylic acid (eight carbons). Harnack and Schwarz (19) showed that $N$-substituted glycine derivatives (especially ethyl and butyl) were systemically effective against Phytophthora infestans in tomato and Septoria apii in celery without being active in vitro.

The interest in amino acid-mediated induced resistance was renewed about 30 years later when we discovered a strong activity of BABA against disease in potato (10), tomato (6), and tobacco (5), and revealed some of the defense mechanisms it activates in tomato (13) and tobacco (5). In recent years, substantial evidence has been accumulated, especially in Arabidopsis mutants, showing that BABA possesses a large spectrum of activity $(7,22,41)$, as well as multiple forms of plant activation against disease $(41,55,66,67)$.

\section{Spectrum of Activity}

Activity of BABA against various plant parasites. Table 1 and Figures 1 to 14 summarize the host-parasite systems in which BABA induced effective resistance. Host plants include annual as well as perennial plants, monocots and dicots belonging to Solanaceae, Cucurbitaceae,

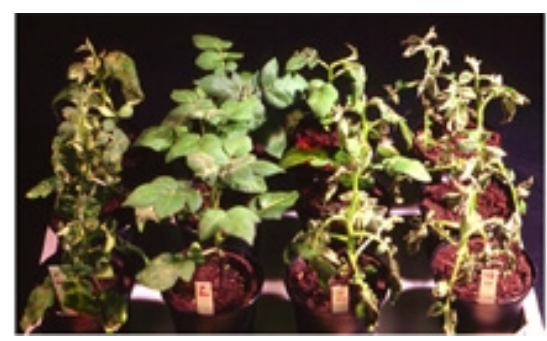

Fig. 1. Protection of potato against Phytophthora infestans by a foliar spray with (left to right): water, DL- $\alpha$-aminobutyric acid (AABA), DL- $\beta$-aminobutyric acid (BABA), $\gamma$-aminobutyric acid (GABA) (2 $\mathrm{mg} / \mathrm{ml})$.
Compositae, Leguminaceae, Cruciferaceae, Graminae, Malvaceae, Rosaceae, and Viniferaceae. Pathogens include oomycetes, fungi, bacteria, TMV, and nematodes. BABA protected against diseases attacking foliage, roots, and fruits. Protection against nematodes was obtained not only by soil drench but also by foliar spray. Translocation of ${ }^{14} \mathrm{C}$-BABA from the foliage to the root (see below) may explain such activity against nematode infection (12). Modes of BABA application include foliar sprays (Fig. 1), soil (root) drenches (Figs. 5 and 13 ), and seed soakage. BABA is also effective when incorporated (as a powder) into the soil, injected into the stem (Fig. 3), or applied as a solution to bare roots, cut stems, or cut leaves. Floating leaf disks are another useful technique to study the efficacy of various derivatives of BABA (Fig. 8) and to study reversal of BABA-induced resistance by various compounds.

The concentration of BABA required to achieve effective ( $\sim 90 \%)$ resistance under controlled conditions depends on the host, the pathogen, and the mode of application (7). Normally, higher doses are required in foliar sprays ( 250 to $1,000 \mu \mathrm{g} \mathrm{ml}^{-1}$ ) than in soil drenches (20 to $100 \mu \mathrm{g} \mathrm{ml}^{-1}$ ), probably because of a more efficient uptake through the root (see below). Highest concentrations ( 0.5 to $1 \%$ solutions) are needed in seed soaking $(7,52)$.

Persistence (duration) of resistance induced by BABA also depends on the pathosystem and mode of application. A single foliar spray on tomato was effective

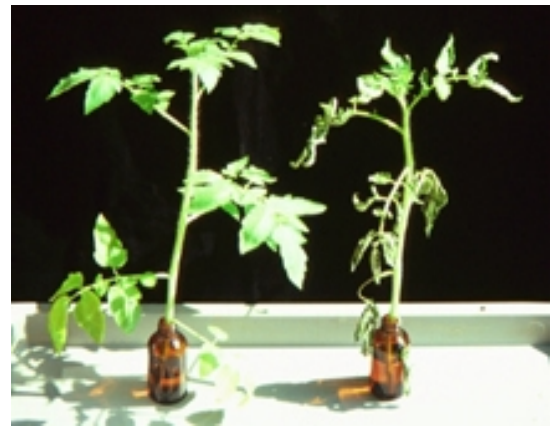

Fig. 2. Protection of tomato against Phytophthora infestans by cut-stem feeding with water (left) or DL- $\beta$-aminobutyric acid (BABA) (right, $1 \mathrm{mg} / \mathrm{ml}$ ). 
Table 1. Pathosystems in which local and systemic resistance were induced by DL- $\beta$-aminobutyric acid

\begin{tabular}{|c|c|c|c|}
\hline Plant & Pathogen & Figure no. & Reference \\
\hline Potato & $\begin{array}{l}\text { Phytophthora infestans } \\
\text { Alternaria solani } \\
\text { Fusarium sambucinum }\end{array}$ & 1 & $\begin{array}{l}(10) \\
(10) \\
(18)\end{array}$ \\
\hline Tomato & $\begin{array}{l}\text { Phytophthora infestans } \\
\text { Botrytis cinerea } \\
\text { Xanthomonas vesicatoria } \\
\text { Fusarium oxysporum } \mathrm{f} . \mathrm{sp} \text {. lycopersici } \\
\text { Clavibacter michiganensis } \\
\text { Meloidogyne javanicum }\end{array}$ & 2,14 & $\begin{array}{l}(6,23-25,39) \\
(10) \\
\text { Y. Cohen (unpublished) } \\
(10,33) \\
(3) \\
(37,38)\end{array}$ \\
\hline Tobacco & $\begin{array}{l}\text { Peronospora tabacina } \\
\text { Phytophthora parasitica var. nicotianae } \\
\text { Tobacco mosaic virus }\end{array}$ & 3,4 & $\begin{array}{l}(5) \\
(7) \\
(55)\end{array}$ \\
\hline Pepper & $\begin{array}{l}\text { Colletotrichum coccodes } \\
\text { Phytophthora capsici }\end{array}$ & & $\begin{array}{l}(20) \\
(20,21)\end{array}$ \\
\hline Cucumber & $\begin{array}{l}\text { Pseudoperonospora cubensis } \\
\text { Sphaerotheca fuliginea } \\
\text { Colletotrichum lagenarium } \\
\text { Pseudomonas lachrymans } \\
\text { Meloidogyne javanicum } \\
\text { Botrytis cinerea }\end{array}$ & & $\begin{array}{l}(7,10,42) \\
(61) \\
\text { A. Meyer, J. Siegrist, Y. Cohen (unpublished) } \\
\text { Y. Cohen (unpublished) } \\
(37,38) \\
(10)\end{array}$ \\
\hline Melon & $\begin{array}{l}\text { Pseudoperonospora cubensis } \\
\text { Fusarium oxysporum f. sp. melonis } \\
\text { Monosporascus cannonballus }\end{array}$ & $\begin{array}{l}5 \\
13\end{array}$ & $\begin{array}{l}(7,10,42) \\
(42) \\
\text { Y. Cohen (unpublished) }\end{array}$ \\
\hline $\begin{array}{l}\text { Watermelon } \\
\text { Arabidopsis }\end{array}$ & $\begin{array}{l}\text { Fusarium oxysporum f. sp. niveum } \\
\text { Peronospora parasitica } \\
\text { Botrytis cinerea } \\
\text { Pseudomonas syringae pv. tomato }\end{array}$ & 5 & $\begin{array}{l}(7) \\
(66) \\
(67) \\
(66)\end{array}$ \\
\hline Cauliflower & $\begin{array}{l}\text { Peronospora parasitica } \\
\text { Pseudomonas marginalis } \\
\text { Pseudomonas fluorescens } \\
\text { Erwinia carotovora subsp. carotovora }\end{array}$ & 11 & $\begin{array}{l}\text { (10,56) } \\
\text { D. Silue (unpublished) } \\
\text { D. Silue (unpublished) } \\
\text { D. Silue (unpublished) }\end{array}$ \\
\hline Broccoli, kohlrabi & Alternaria brassicicola & & $(7,10)$ \\
\hline Sunflower & $\begin{array}{l}\text { Plasmopara halstedii } \\
\text { Puccinia helianthi }\end{array}$ & & $\begin{array}{l}(7,10,59) \\
\text { Y. Cohen (unpublished) }\end{array}$ \\
\hline Lettuce & Bremia lactucae & & (44) - - 1 \\
\hline Carnation & Fusarium oxysporum f. sp. dianthi & & Y. Ben-Yefet and Y. Cohen (unpublished) \\
\hline $\begin{array}{l}\text { Cereals (wheat, oats, } \\
\text { barley) }\end{array}$ & $\begin{array}{l}\text { Heterodera lalipons } \\
\text { Heterodera avenae }\end{array}$ & & $\begin{array}{l}(36,38) \\
(36,38)\end{array}$ \\
\hline Maize & Fusarium moniliforme & & (8) \\
\hline Pear millet & Sclerospora graminicola & & $(52)$ \\
\hline Pea & Aphanomyces euteiches & & (45) \\
\hline Peanut & Cercosporidium personatum & & $(64,65)$ \\
\hline Grapes & Plasmopara viticola & $8,9,10,12$ & $(14,48)$ \\
\hline Apple fruit & Alternaria alternata & & M. Reuveni and Y. Cohen (unpublished) \\
\hline Cotton & $\begin{array}{l}\text { Verticillium dahliae } \\
\text { Fusarium oxysporum f. sp. vasinfectum }\end{array}$ & & $\begin{array}{l}\text { (33) } \\
\text { Y. Cohen (unpublished) }\end{array}$ \\
\hline
\end{tabular}

Table 2. Area under disease progress curve (AUDPC) and percent control of potato late blight epidemics caused by a metalaxyl insensitive isolate of Phytophthora infestans following treatment with DL- $\beta$-aminobutyric acid (BABA) in three field experiments

\begin{tabular}{|c|c|c|c|c|c|c|c|}
\hline \multirow[b]{3}{*}{ Experiment, cultivar } & \multirow[b]{3}{*}{ BABA kg ha-1 } & \multicolumn{6}{|c|}{ Interval between sprays (days) } \\
\hline & & \multicolumn{2}{|c|}{7} & \multicolumn{2}{|c|}{10} & \multicolumn{2}{|c|}{14} \\
\hline & & AUDPC $^{\mathbf{a}}$ & Control (\%) & AUDPC & Control (\%) & AUDPC & Control (\%) \\
\hline \multirow[t]{4}{*}{ Autumn, Alpha } & 0 & $\ldots$ & $\ldots$ & $\ldots$ & $\ldots$ & $1,637 \mathrm{a}$ & 0 \\
\hline & 0.2 & $\ldots$ & $\ldots$ & $\ldots$ & $\ldots$ & $1,234 \mathrm{~b}$ & 24.6 \\
\hline & 0.4 & $\ldots$ & $\ldots$ & $\ldots$ & $\ldots$ & $776 \mathrm{c}$ & 52.6 \\
\hline & 0.8 & $\ldots$ & $\ldots$ & $\ldots$ & $\ldots$ & $735 c$ & 55.1 \\
\hline \multirow[t]{4}{*}{ Winter, Bintje } & 0 & $756 \mathrm{a}$ & 0 & $756 a$ & 0 & $756 a$ & 0 \\
\hline & 0.2 & $340 \mathrm{~b}$ & 55.0 & $438 \mathrm{~b}$ & 42.1 & $466 \mathrm{~b}$ & 38.4 \\
\hline & 0.4 & $322 \mathrm{~b}$ & 57.4 & $359 \mathrm{bc}$ & 52.5 & $400 \mathrm{bc}$ & 47.1 \\
\hline & 0.8 & $283 \mathrm{~b}$ & 62.6 & $283 \mathrm{c}$ & 62.6 & $318 \mathrm{c}$ & 58.0 \\
\hline \multirow[t]{3}{*}{ Spring, Alpha } & 0 & $475 \mathrm{a}$ & 0 & $\ldots$ & $\ldots$ & $\ldots$ & $\ldots$ \\
\hline & 0.57 & $295 \mathrm{~b}$ & 38.0 & $\ldots$ & $\ldots$ & $\ldots$ & $\ldots$ \\
\hline & 1.15 & $106 \mathrm{c}$ & 77.7 & $\ldots$ & $\ldots$ & $\ldots$ & $\ldots$ \\
\hline \multirow[t]{3}{*}{ Spring, Bintje } & 0 & $935 \mathrm{a}$ & 0 & $\ldots$ & $\ldots$ & $\ldots$ & $\ldots$ \\
\hline & 0.57 & $606 \mathrm{~b}$ & 35.2 & $\ldots$ & $\ldots$ & $\ldots$ & $\ldots$ \\
\hline & 1.15 & $332 \mathrm{c}$ & 64.5 & $\ldots$ & $\ldots$ & $\ldots$ & $\ldots$ \\
\hline
\end{tabular}




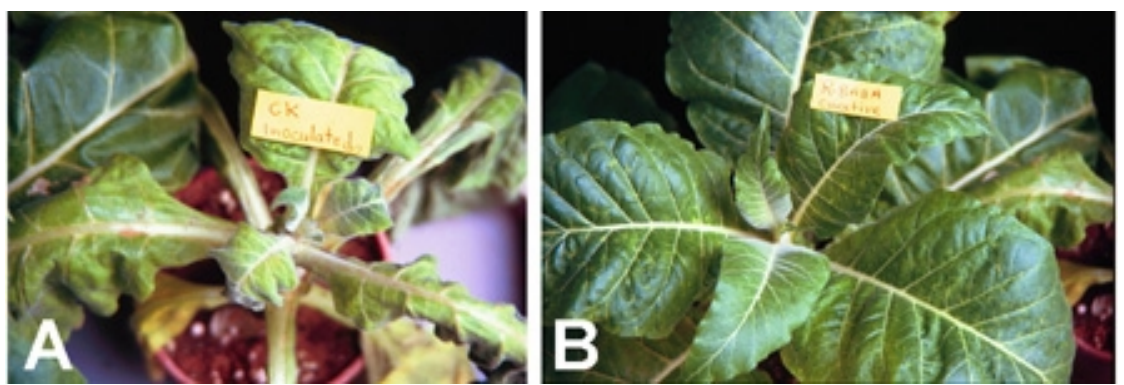

Fig. 3. Curative protection of tobacco against Peronospora tabacina. A, Plant treated with water, and $B$, plant receiving stem injection of DL- $\beta$-aminobutyric acid (BABA) 1 day after inoculation.
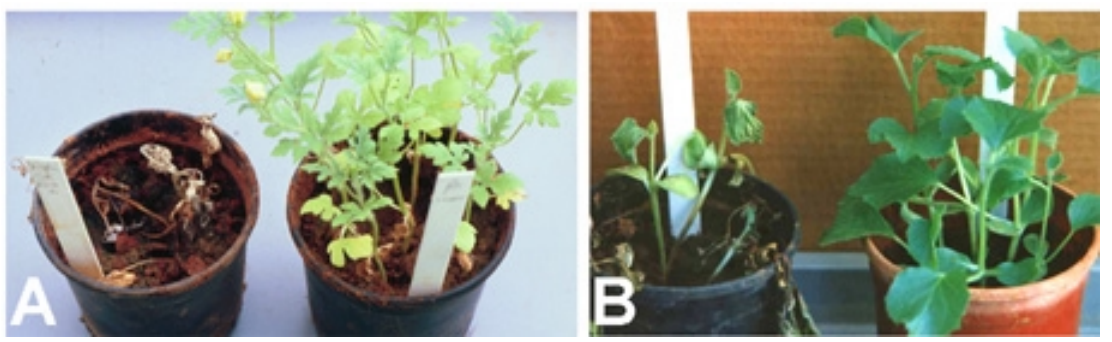

Fig. 5. Control of Fusarium wilt of: A, watermelon (Fusarium oxysporum f. sp. niveum) and $B$, muskmelon ( $F$. oxysporum f. sp. melonis) following a soil drench of DL- $\beta$ aminobutyric acid (BABA) at $20 \mathrm{mg} \mathrm{kg}^{-1}$ soil. Plants on right were drenched with water only.

\section{Tobacco, PR-1}
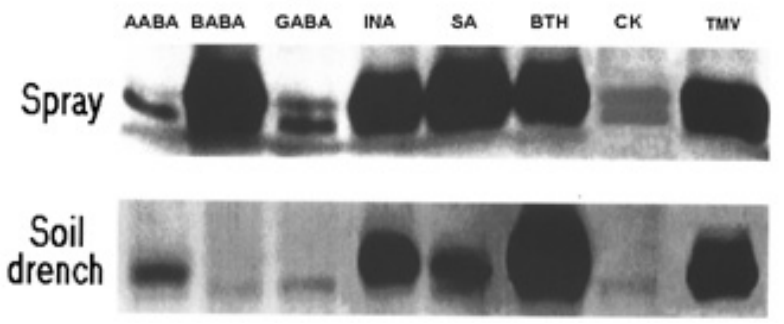

Fig. 6. Immunoblot of pathogenesis-related protein PR-1 accumulation in tobacco 'Xanthi nc' treated with a foliar spray or a soil drench of (left to right) $D L-\alpha$-aminobutyric acid (AABA), DL- $\beta$-aminobutyric acid (BABA), $\gamma$-aminobutyric acid (GABA), 2,6-dichloroisonicotinic acid (INA), salicylic acid (SA), benzo[1,2,3] thiadiazole-7-carbothionic acid S-methyl ester (BTH), or water, or inoculated with Tobacco mosaic virus as a positive control. Note lack of PR-1 accumulation when BABA was applied as a soil drench.

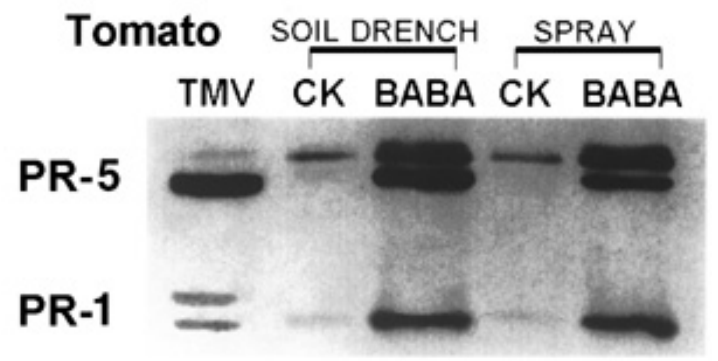

Fig. 7. Immunoblot of pathogenesis-related proteins PR-1 and PR-5 from tomato treated with water (CK) or DL- $\beta$-aminobutyric acid (BABA) by a soil drench or a foliar spray. Note PR protein accumulation in both methods of application.

for 12 days against $P$. infestans (6), whereas a seed treatment of pearl millet was effective against Sclerospora graminicola for 30 days (52).

Unlike other plant activators (e.g., SA, INA, BTH), which provide resistance only when applied before pathogen infection $(26,57)$, BABA exhibited postinfectional activity when applied 1 to 3 days after inoculation. This was true in tomato against $P$. infestans (6), tobacco against Peronospora tabacina (5) (Figs. 6 and 7),

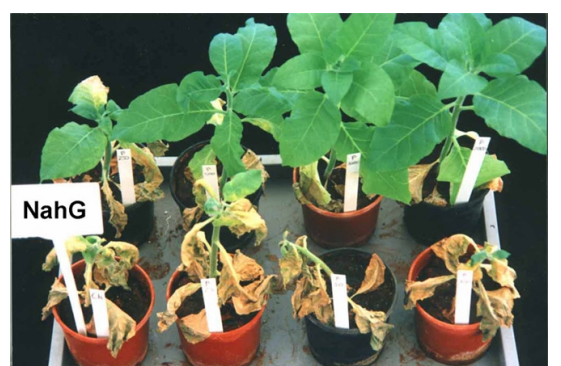

Fig. 4. Protection of NahG tobacco against Peronospora tabacina. Clockwise from bottom right are plants treated with a foliar application of DL- $\beta$ aminobutyric acid (BABA) at $0,16,31$, $62,125,250,500,2,000$, and $1,000 \mu \mathrm{g} / \mathrm{ml}$.

grapes against Plasmopara viticola (14), and cauliflower against Peronospora parasitica (56). Zimmerli et al. (66) applied BABA to the root of Arabidopsis plants 6 days after inoculation with Peronospora parasitica and observed no inhibition of sporulation on the seventh day. They concluded treatment had no curative effect. We observed a strong suppression of sporulation by Peronospora parasitica in Arabidopsis plants treated with BABA 1 or 2 days (99.6 and $86.0 \%$ spore reduction, respectively) after inoculation. When BABA was applied 5 days after inoculation, abundant sporulation occurred.

Performance in the greenhouse and field. The efficacy of BABA in controlling downy mildew of grape (Plasmopara viticola) was tested in the field for three consecutive years in Israel with comparison to standard fungicides and BTH (Bion or Actigard) (48). Two sprays at 14-day intervals with 0.1 or $0.2 \%$ BABA suppressed disease development by 60 and $92 \%$, respectively, compared with untreated control plots. BABA was as effective as the standard metalaxyl-copper hydroxide (Ridomil- $\mathrm{Cu}$ ) fungicide treatment and was significantly better than applications of fosetyl-A1, folpet, or Bion (48) (Fig. 12).

In field experiments, application of BABA at 14-day intervals resulted in about $60 \%$ control of late blight in potato (10). More frequent sprays of $\mathrm{BABA}$ at reduced rates increased efficacy (Table 2). Maximum efficacy was seen at $1.15 \mathrm{~kg} \mathrm{ha}^{-1}$ applied four times at 7-day intervals (64.5 to $77.7 \%$ control of the disease) (Table 2). Two BABA applications at 14-day intervals to field-grown tomato resulted in about $83 \%$ control (Y. Cohen, unpublished) of the disease, indicating that BABA is more effective against $P$. infestans in tomato than in potato (Fig. 14).

BABA (1 mg ml$\left.{ }^{-1}\right)$, applied through the drip-irrigation system at 2-week intervals, was effective against sudden wilt of melon caused by Monosporascus cannonballus (Fig. 13).

BABA also was effective against leaf spot disease in peanuts (64) in the United States. Zhang et al. (65) compared the 
efficacy of SA, INA, BTH, and BABA in inducing resistance against leaf spot in peanut caused by Cercosporidium personatum. In the greenhouse, BABA was the only inducer that significantly reduced disease incidence (by 68\% in one experiment and 34\% in another). In the field, leaf spot severity after 90 days in nontreated plots was $4.6(0=$ no disease, $10=$ dead plants) compared with 3.6 in BABAtreated plots. Plots treated with the fungicide chlorothalonil (Bravo) had a disease severity of 2.9, whereas BABA applied in combination with Bravo resulted in a severity of 1.9 , suggesting synergistic action between the two components. BABA also was synergistic with a plant growth promoting rhizobacterial (PGPR) strain.

Shailasree et al. (52) examined the effect of BABA on infection of pearl millet by the downy mildew pathogen Sclerospora graminicola. They showed that stirring seeds of pearl millet in BABA $(50 \mathrm{mM}$ for $6 \mathrm{~h}$ at $26^{\circ} \mathrm{C}$ ) protected up to $75 \%$ of the emerging seedlings from downy mildew without affecting seed germination or seedling vigor. Downy mildew biomass in BABA-protected plants was reduced by $90 \%$ relative to unprotected, control plants. These BABA-treated plants were then reinoculated with $\mathrm{S}$. graminicola after 1 month by placing inoculum in leaf-whorls and inflorescence axes. The treated plants exhibited $10 \%$ infection of the primary tillers and $12 \%$ infection of the inflorescences compared with 71 and $76 \%$ infection, respectively, in the same tissues of plants grown from untreated seed. Control plants exhibited 71 and $76 \%$ downy mildew infection in the primary tillers and inflorescence, respectively, compared with 10 and $12 \%$ in the BABA-treated plants. This demonstrated a durable action of BABA. BABA also enhanced vegetative and reproductive growth of pearl millet.

Synergistic interactions. We observed that BABA was not effective in inducing resistance against powdery mildews. However, when mixed with triazole fungicides, it greatly enhanced their effectiveness. For example, application of propiconazole at $0.5 \mu \mathrm{g} \mathrm{ml}^{-1}$ and BABA at $250 \mu \mathrm{g} \mathrm{ml}^{-1}$ reduced infection of powdery mildew in wheat by 25 and $17 \%$, respectively. When the two were mixed, mildew infection was reduced by $87 \%$. Similarly, powdery mildew was reduced on barley and cucumber by using mixtures of BABA and other triazole fungicides (9).

BABA is synergistic with many other fungicides as well as with other plant activators (11) and PGPR (65). Mixtures of BABA with either copper hydroxide, cymoxanil, fosetyl-A1, dimethomorph, mancozeb, chlorothalonil, folpet, metalaxyl, or BHT (Bion) greatly enhanced protection of tomato against $P$. infestans, tobacco against Peronospora tabacina, grapes against Plasmopara viticola, and cucumber against Pseudoperonospora cubensis.
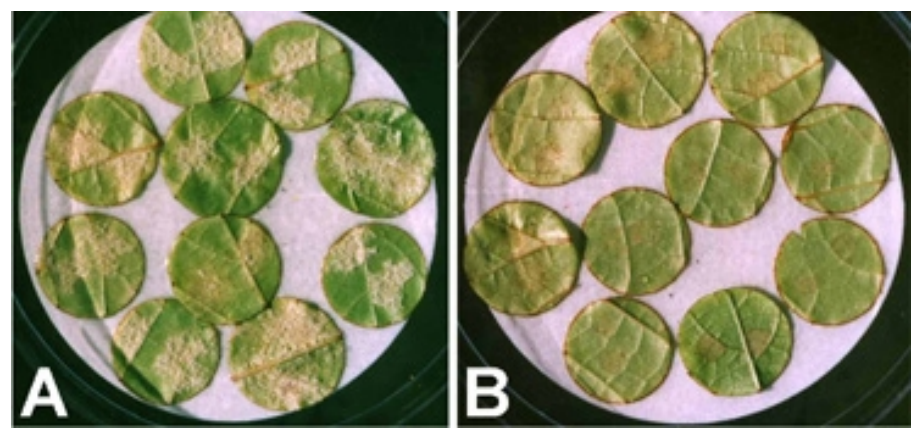

Fig. 8. Sporulation of Plasmopara viticola on grape leaf disks floated on A, water or $B$, a solution of $\mathrm{DL}-\beta$-aminobutyric acid (BABA) $\left(25 \mathrm{\mu g} \mathrm{ml}^{-1}\right)$.

Table 3. Enhanced activity of DL- $\beta$-aminobutyric acid (BABA) in mixtures with metalaxyl or BTH in controlling downy mildew in tobacco caused by two isolates of Peronospora tabacina

\begin{tabular}{|c|c|c|c|c|}
\hline \multirow[b]{2}{*}{ Treatment $^{\mathrm{a}}$} & \multicolumn{2}{|c|}{ Metalaxyl-sensitive isolate } & \multicolumn{2}{|c|}{ Metalaxyl-insensitive isolate } \\
\hline & $\begin{array}{c}\mathbf{E D}_{90}{ }^{\mathrm{b}} \\
\text { mg liter }^{-1}\end{array}$ & $\begin{array}{l}\text { Synergy } \\
\text { factor }^{\mathbf{c}}\end{array}$ & $\begin{array}{c}\mathbf{E D}_{90} \\
\text { mg liter-1 }\end{array}$ & $\begin{array}{l}\text { Synergy } \\
\text { factor }\end{array}$ \\
\hline BABA & 78 & $\ldots$ & 406 & $\ldots$ \\
\hline metalaxyl & 0.2 & $\ldots$ & 416 & $\ldots$ \\
\hline BTH & 52 & $\ldots$ & 88 & $\ldots$ \\
\hline \multicolumn{5}{|c|}{ BABA:metalaxyl } \\
\hline $7.5: 1$ & 0.5 & 3.3 & 150 & 2.7 \\
\hline $10: 1$ & 0.4 & 5.4 & 145 & 2.8 \\
\hline $15: 1$ & 4.3 & 2.1 & 282 & 1.4 \\
\hline \multicolumn{5}{|l|}{$\mathrm{BABA}+\mathrm{BTH}$} \\
\hline $7.5: 1$ & 15 & 4.9 & 90 & 3.1 \\
\hline 10:1 & 4 & 18.7 & 52 & 5.9 \\
\hline $15: 1$ & 5 & 15.1 & 186 & 1.8 \\
\hline
\end{tabular}

a Ten-leaf tobacco (cv. Xanthii nc) plants were sprayed with the compounds or compound mixtures at a final concentration of $0,62,125$, and $250 \mathrm{mg} \mathrm{liter}^{-1}$ and challenged 2 days later with 10,000 spores of $P$. tabacina per ml. Disease severity was evaluated 10 days after inoculation. Ratios represent the proportion (based on weights of active ingredient) of BABA, metalaxyl, and BTH in the final mixture.

${ }^{\mathrm{b}}$ Dose required to achieve $90 \%$ control of the disease.

${ }^{c}$ Synergy factor sensu Wadley (62).

Table 4. Systemic translocation of ${ }^{14} \mathrm{C}$ - DL- $\beta$-aminobutyric acid (BABA) in tomato and potato

\begin{tabular}{lcccc}
\hline & \multicolumn{3}{c}{ \% applied ${ }^{14}$ C-BABA recovered } \\
\cline { 2 - 5 } Organ & \multicolumn{3}{c}{ Tomato } & \multicolumn{3}{c}{ Potato $^{\text {a }}$} \\
\cline { 2 - 5 } Treated leaves & 9.30 & $(41.4)$ & 14.82 & $(56.5)$ \\
Untreated leaves & 8.55 & $(38.1)$ & 2.13 & $(8.1)$ \\
Stem & 2.85 & $(12.7)$ & 1.21 & $(4.6)$ \\
Root & 1.75 & $(7.8)$ & 0.38 & $(1.4)$ \\
Tubers & $\ldots$ & $\ldots$ & 7.67 & $(29.3)$ \\
Total recovered & 22.45 & $(100)$ & 26.21 & $(100)$
\end{tabular}

a Two middle leaflets on each plant were treated with $1 \mu \mathrm{Ci}$ of BABA (total of $2 \mu \mathrm{Ci}$ per plant). Values represent percentages of the total amount of ${ }^{14} \mathrm{C}-\mathrm{BABA}$ applied that was extracted from plant tissues by a methanol:chloroform:water technique 2 and 5 days after treatment on tomato (cv. Baby) and potato (cv. Bintje), respectively. Values in parentheses represent percentages of extracted ${ }^{14} \mathrm{C}-\mathrm{BABA}$ found in each tissue.

The synergistic interactions between BABA and the fungicide metalaxyl or the plant activator BTH are given in Table 3 . BABA was mixed at various concentrations with either metalaxyl or BTH and applied to tobacco plants. Treated plants were then challenged with one of two isolates of Peronospora tabacina that differed in sensitivity to metalaxyl. The metalaxylinsensitive isolate was also more aggres- sive than the metalaxyl-sensitive isolate to both BTH- and BABA-treated plants. Results in Table 3 show that mixtures were more effective than expected, giving a relatively high level $(90 \%)$ of disease control at reduced concentrations of each compound.

BABA also was synergistic with chitosan in the control of Fusarium sambucinum in potato tubers (18) and with 


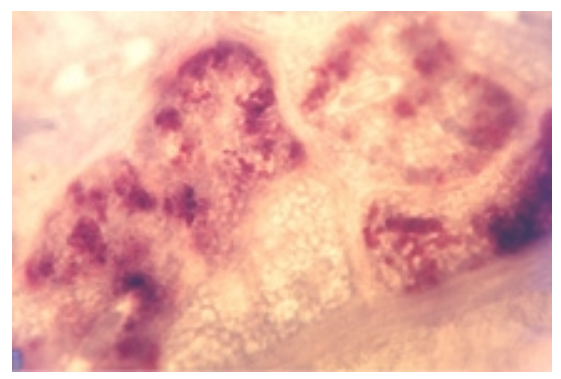

Fig. 9. Photomicrograph showing accumulation of lignin in $D L-\beta$-aminobutyric acid (BABA)-treated grape leaf disks inoculated with Plasmopara viticola. potassium phosphite in controlling rootknot nematodes in tomato and cucumber $(36,38)$.

\section{Uptake, Translocation, and Fate}

Uptake into plant tissue. When ${ }^{14} \mathrm{C}$ BABA was applied to the surface of tomato leaves, about $9 \%$ was recovered from inside that leaf after 1 day. Further uptake occurred with time, and about $13 \%$ of the applied label could be recovered after 4 days (12). Preventing the droplets from drying on the leaf surface facilitated uptake. Thus, leaf disks enclosed in petri dishes for $72 \mathrm{~h}$ may take up as much as

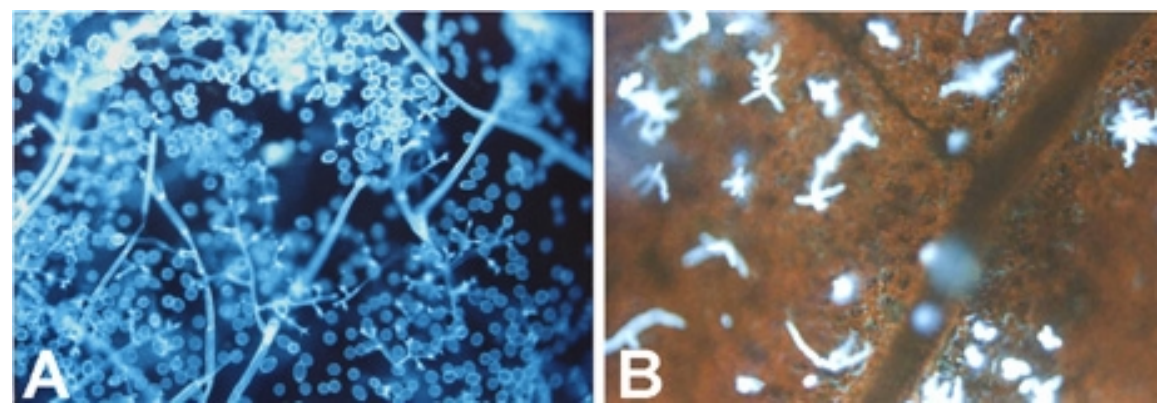

Fig. 10. Sporulation of Plasmopara viticola on grape leaf disks floated in A, water or $B$, a solution DL- $\beta$-aminobutyric acid (BABA) $\left(25 \mu \mathrm{g} / \mathrm{ml}^{-1}\right)$. Note the small distorted sporangiophores and lack of sporulation in the BABA-treated disks.
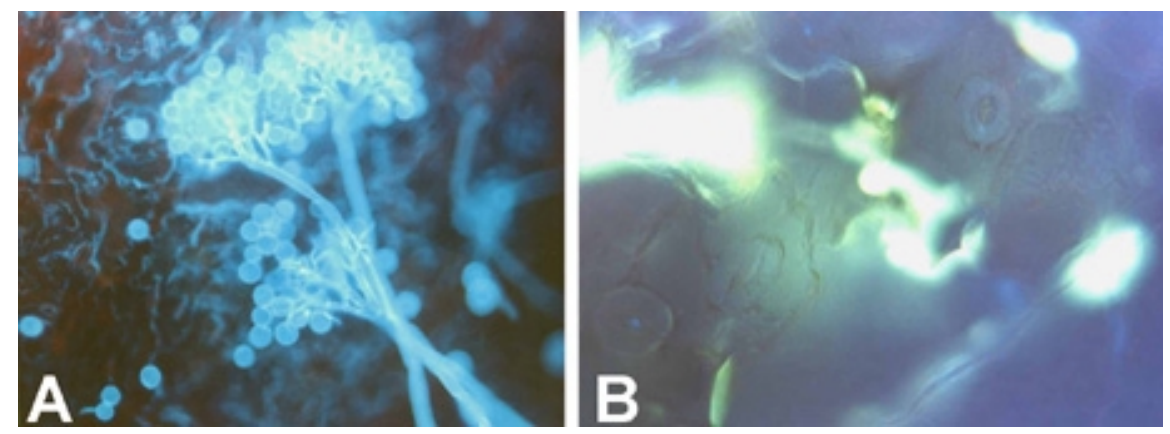

Fig. 11. Sporulation of Peronospora parasitica on cauliflower leaf treated with A, water or $B, D L-\beta$-aminobutyric acid (BABA) $\left(1 \mathrm{mg} \mathrm{ml}^{-1}\right)$. Note heavy callose deposition on BABA-treated leaf.
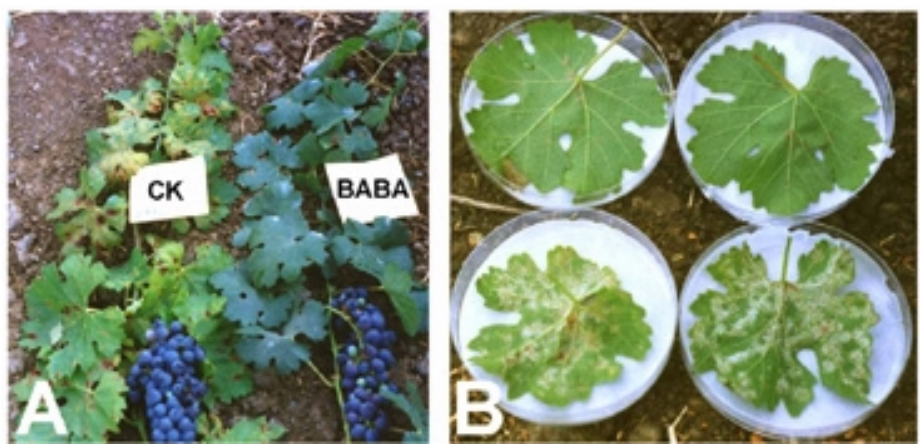

Fig. 12. A, Control of Plasmopara viticola on grape in the field following two applications of DL- $\beta$-aminobutyric acid (BABA) at 14-day intervals. B, Note heavy sporulation on untreated leaves (bottom) compared with those treated with BABA (top). Similar results were obtained by applying BABA to the soil.

$73 \%$ of the compound (12). Uptake was dependent on leaf age. In grapes, the percent uptake through the abaxial surface of attached bottom, middle, or upper leaves was $5,3.5$, and $30 \%$, respectively, suggesting that the higher rate of uptake by young foliage probably resulted from a thinner cuticle layer (14).

Rate of uptake was positively correlated with the degree of resistance induced against disease. To achieve about $90 \%$ protection against late blight, intact tomato plants had to be sprayed with a solution of about $1,000 \mu \mathrm{g} \mathrm{m}^{-1}$ (6) (Fig. 2), whereas only $12.5-\mu \mathrm{g} \mathrm{ml} \mathrm{m}^{-1}$ BABA was required when leaf disks were floated on the solution.

Uptake through the cut end petiole of detached leaves reached $100 \%$ in $2 \mathrm{~h}$ (12), whereas uptake via the root system reached $36 \%$ in 2 days (12), suggesting that uptake is facilitated by a specific transporter. A specific transporter for GABA has been reported for tomato pollen (51).

Translocation. Translocation of ${ }^{14} \mathrm{C}$ BABA in plants was studied with the aim of correlating it with induced resistance. When applied to tomato leaves, labeled BABA translocated within 2 days into the actively growing parts of the shoot and root (12). Uptake and systemic translocation in potato was different from tomato (Table 4). BABA accumulated in potato tubers, suggesting phloem mobility of the compound. BABA did not translocate from younger leaves to older leaves of tomato or potato. In grapes (14), translocation occurred from a middle leaf into the upper (younger) leaves, but not to the older ones. Translocation to the root was more pronounced when ${ }^{14} \mathrm{C}$-BABA was applied to a bottom grape leaf (14).

Injecting ${ }^{14} \mathrm{C}-\mathrm{BABA}$ into the stem base of tobacco plants resulted in an elevated gradient of labeled product in leaves along the shoot, with about 1,3 , and $20 \%$ of the labeled amino acid recovered from bottom, middle, and upper leaves, respectively.

In both tomato (12) and Arabidopsis (22), ${ }^{14} \mathrm{C}$-BABA was rapidly taken up by the root system and accumulated mainly in the younger parts of the shoot. In all experiments, translocation was positively correlated with resistance $(12,22)$.

BABA translocation from roots to leaves apparently occurs via the xylem, since girdling the stem cortex of tomato plants before feeding their roots with BABA did not reduce the high level of protection against $P$. infestans (12). Placing petioles of detached leaves in a solution of ${ }^{14} \mathrm{C}$ BABA resulted in complete uptake of the amino acid within $2 \mathrm{~h}$ after application, suggesting a rapid translocation via the xylem (12).

BABA, like other amino acids (2), appears to be translocated from a treated leaf via the phloem into the stem, from which it can translocate acropetally to the young leaves or basipetally to the root and tuber, 
which act as sinks. It probably can relocate from the top leaves to the root and tubers along with other assimilates. When applied to the root, cut petiole end, or injected into the stem, it moves acropetally via the transpiration stream.

Metabolism and fate of BABA. BABA remains mostly unmetabolized in plant tissues. The majority of ${ }^{14} \mathrm{C}$-BABA taken up by tomato (12), tobacco, or Arabidopsis $(22,66)$ could be recovered by a methanol:chloroform:water (MCW) extraction technique normally used for amino acids (1). However, a small fraction (3 to 5\%) of labeled BABA was retained by the tissue and could not be recovered by MCW extraction (12). The ${ }^{14} \mathrm{C}$ associated with the cell wall fraction of tobacco accounted for $0.6 \%$ of the total amount injected. This ${ }^{14} \mathrm{C}$ could be released from the cell wall fraction of tobacco only after enzymic digestion with $0.1 \%$ Proteinase-K and to a lesser extent by $0.5 \%$ pectinase, but not with cellulase $(2 \%)$ or hemicellulase $(2 \%)$ (P. Schweizer and Y. Cohen, unpublished), suggesting incorporation into cell-wall proteins. The released ${ }^{14} \mathrm{C}$-labeled proteins, precipitated by ammonium sulfate, had a molecular weight of $40 \mathrm{kDa}$. Whether this cell-wall-associated BABA protein has any role in resistance is not clear. Some fortifi- cation of tomato and tobacco leaf tissue was observed after BABA treatment because enzymatic maceration of the cell walls was slower in BABA-treated leaf disks (41).

\section{Mode of Action of BABA}

BABA induces a variety of physical and biochemical defense mechanisms in plants (Table 5).

Physical barriers. When applied as a foliar spray, BABA induces the formation of pinpoint necrotic spots which were considered by some researchers to be involved in $\operatorname{SAR}(55,66)$. The role of such necrotic spots in SAR is questioned because AABA also produces necrotic spots $(5,6)$, while inducing only a weak resistance.

Trailing necrosis (i.e., necrosis surrounding the developing hyphae), enhanced callose formation, and papillae were observed in Arabidopsis plants treated with BABA after a challenge inoculation with Peronospora parasitica. Cauliflower leaves treated with BABA and then inoculated with Peronospora parasitica developed callose that encased haustoria (Fig. 11). In tomato challenged with $P$. infestans, callose $(24,25)$ and both callose and lignin (47) were observed. In grapes, lignin was accumulated following inocula- tion with Plasmopara viticola (14) (Figs. 8 and 9), whereas in tobacco inoculated with Peronospora tabacina, neither callose nor lignin was formed (5). It thus appears that a physical barrier(s) induced by BABA is pathosystem-specific.

Pathogenesis-related proteins. A similar pathosystem-specific behavior was seen with pathogenesis-related (PR) protein accumulation (Table 6). In tomato and pepper, PR proteins accumulated after a foliar spray $(13,21)$ or soil drench $(21,41)$ (Fig. 7), regardless of inoculation with a pathogen. Accumulation of PR proteins was further enhanced in tomato (23) and pepper (21) following inoculation with $P$. infestans or Phytophthora capsici, respectively. A foliar spray (but not a soil drench or stem injection of $\mathrm{BABA}$ ) also induced PR protein accumulation in tobacco before challenge (5,55) (Fig. 6). However, all application methods resulted in SAR against Peronospora tabacina (5), suggesting that PR protein accumulation was not the sole mechanism responsible for resistance.

In tomato (23) and tobacco (55), PR proteins were accumulated systemically. Jakab et al. (22) reported that in Arabidopsis, BABA applied as foliar spray, even at low concentrations, induced the accumulation
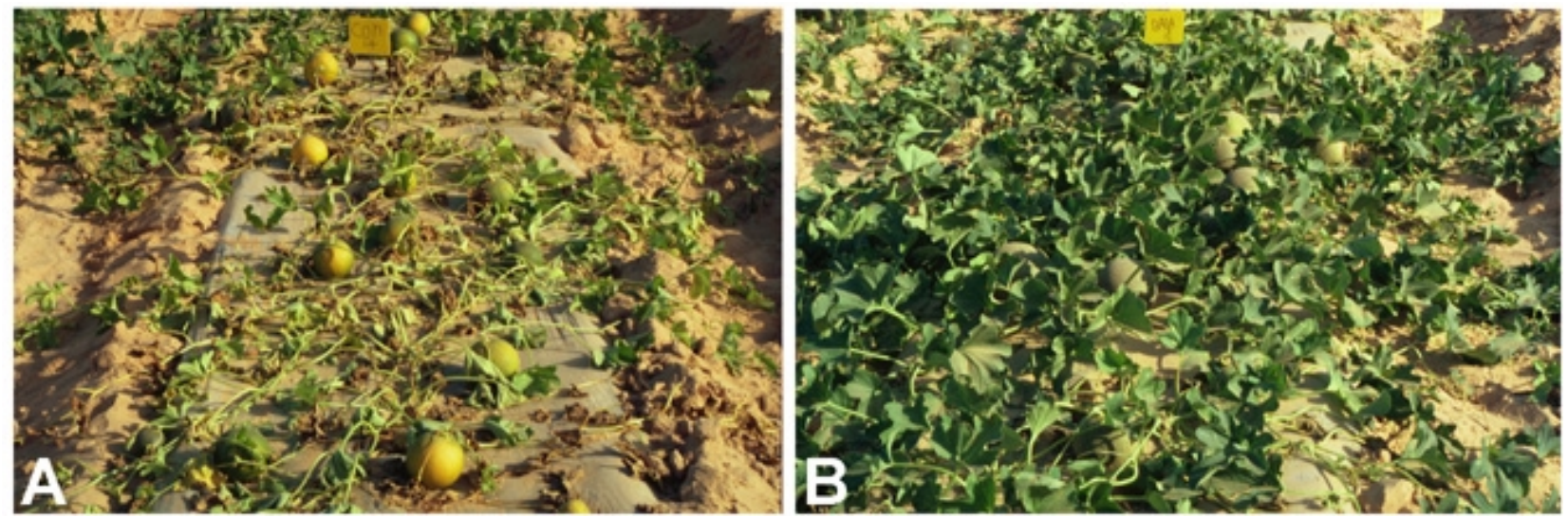

Fig. 13. Control of sudden wilt of melon (Monosporascus cannonballus). A, Untreated and B, treated with two soil applications of DL- $\beta$-aminobutyric acid (BABA) (0.1 g per plant) at 14-day intervals.
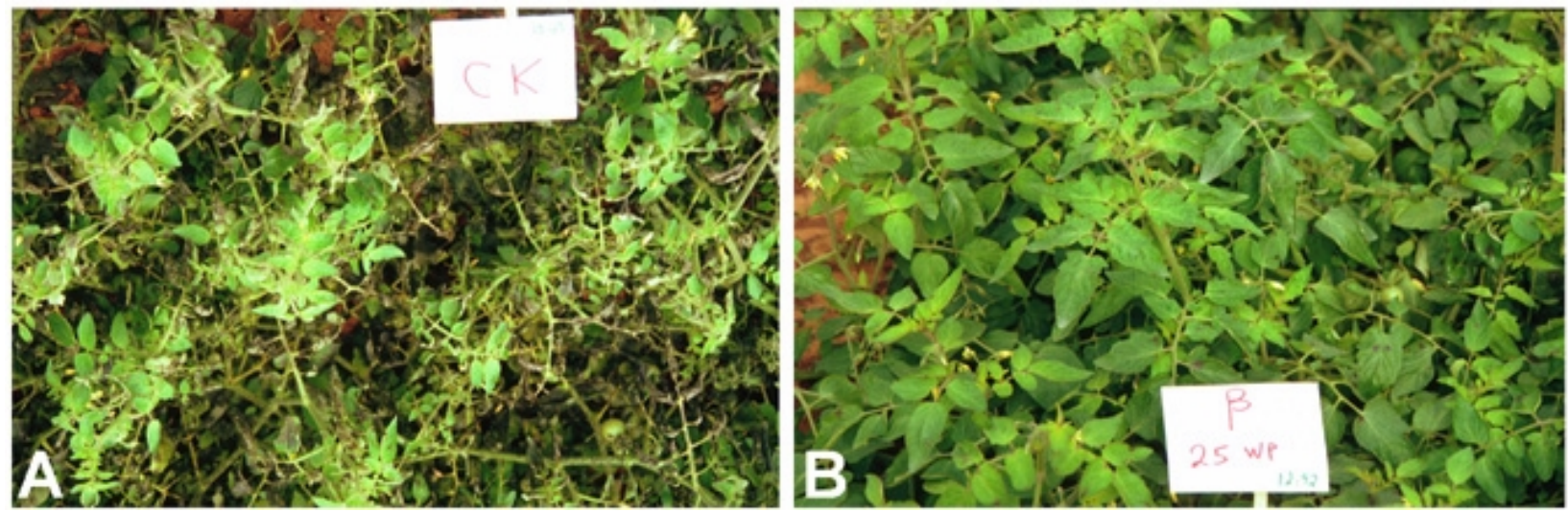

Fig. 14. Protection of tomato against Phytophthora infestans in the field. A, Untreated and B, treated with DL- $\beta$-aminobutyric acid (BABA). 
of SAR proteins (PR1, PR2, and PR5) but a soil drench at the same concentrations did not. As both methods of application induced resistance, they also concluded that expression of resistance is independent of PR proteins (22).
Arabidopsis and cauliflower PR proteins did not accumulate following a soil drench with BABA. However, a challenge inoculation with either Pseudomonas syringe pv. tomato (66), Botrytis cinerea (67), or Peronospora parasitica (56) accelerated PR

Table 5. Compounds associated with disease resistance in DL- $\beta$-aminobutyric acid (BABA)treated plants

\begin{tabular}{|c|c|c|c|}
\hline Plant & Accumulating compounds & Tissue & Reference \\
\hline \multirow[t]{7}{*}{ Tomato } & Phenolics & Root & (3) \\
\hline & Autofluorescing compounds & Leaf & (47) \\
\hline & Callose, lignin & Leaf & $(25,47)$ \\
\hline & PR-proteins & Root, leaf & $(13,23,24,41)$ \\
\hline & Amino acids & Leaf & This study \\
\hline & Salicylic acid & Root, leaf & $(23)$ \\
\hline & Hydrogen peroxide & Leaf & (47) \\
\hline \multirow[t]{6}{*}{ Tobacco } & Hydrogen peroxide & Leaf & $(55)$ \\
\hline & Superoxide & Leaf & $(55)$ \\
\hline & Lipid peroxides & Leaf & $(55)$ \\
\hline & PR-proteins & Leaf & $(5,55,63)$ \\
\hline & Salicylic acid & Leaf & $(55)$ \\
\hline & Callose & Leaf & $(55)$ \\
\hline \multirow[t]{3}{*}{ Pepper } & PR-proteins & Stem & (21) \\
\hline & Phytoalexins & Stem & $(21)$ \\
\hline & Salicylic acid & Stem & (21) \\
\hline \multirow[t]{2}{*}{ Arabidopsis } & Callose & Leaf & (66) \\
\hline & PR-proteins & Leaf & $(66,67)$ \\
\hline \multirow[t]{2}{*}{ Cauliflower } & Callose & Leaf & This study \\
\hline & PR-proteins & Leaf & $(56)$ \\
\hline Grape & Lignin & Leaf & (14) \\
\hline Parsley & Furanscoumarins & Cells & $(53,54)$ \\
\hline
\end{tabular}

Table 6. Pathogenesis related (PR) protein accumulation in plants treated with DL- $\beta$ aminobutyric acid (BABA) before or after challenge with a pathogen

\begin{tabular}{|c|c|c|c|c|}
\hline \multirow{2}{*}{$\begin{array}{l}\text { Plant - } \\
\text { pathogen }\end{array}$} & \multirow{2}{*}{$\begin{array}{c}\text { Mode BABA } \\
\text { application }\end{array}$} & \multicolumn{2}{|c|}{ PR-proteins accumulation } & \multirow[b]{2}{*}{ Reference } \\
\hline & & Before challenge & After challenge & \\
\hline $\begin{array}{l}\text { Tomato - } \\
\text { Phytophthora } \\
\text { infestans }\end{array}$ & Foliar spray & PR-1, PR-2, PR-5 & Not tested & (13) \\
\hline $\begin{array}{l}\text { Tomato - } \\
\text { Phytophthora } \\
\text { infestans }\end{array}$ & Root drench & PR-1, PR-5 (PR-2 nt) & Not tested & $(41)$ \\
\hline $\begin{array}{l}\text { Tomato - } \\
\text { Phytophthora } \\
\text { infestans }\end{array}$ & Foliar spray & $\begin{array}{l}\text { P14, AP24 } \\
\text { Local and systemic }\end{array}$ & $\begin{array}{l}\mathrm{P} 14 \text {, also in } \\
\text { fungus and } \\
\text { papillae, AP24 }\end{array}$ & $(23,24)$ \\
\hline Tobacco - & Foliar spray & PR-1, PR-2, PR-5 & Not tested & (5) \\
\hline Peronospora & Root drench & None & Not tested & (5) \\
\hline tabacina & Stem injection & PR-5 & Not tested & (5) \\
\hline $\begin{array}{l}\text { Tobacco - } \\
\text { Tobacco mosaic } \\
\text { virus }\end{array}$ & Foliar spray & $\begin{array}{l}\text { PR-1 (mRNA) } \\
\text { PR-1 Gus promoter, } \\
\text { Local and systemic }\end{array}$ & Not tested & $(55)$ \\
\hline Arabidopsis - & Foliar spray & PR-1, PR-2, PR-5 (mRNA) & Not tested & $(22)$ \\
\hline $\begin{array}{l}\text { Peronospora } \\
\text { parasitica }\end{array}$ & Root drench & None & Not tested & (66) \\
\hline $\begin{array}{l}\text { Arabidopsis - } \\
\text { Botrytis cinerea }\end{array}$ & Root drench & None & PR-1 (mRNA) & $(67)$ \\
\hline $\begin{array}{l}\text { Arabidopsis - } \\
\text { Pseudomonas } \\
\text { syringae pv. } \\
\text { tomato }\end{array}$ & Root drench & None & PR-1 (mRNA) & $(66)$ \\
\hline $\begin{array}{l}\text { Cauliflower - } \\
\text { Peronospora } \\
\text { parasitica }\end{array}$ & Foliar spray & None & PR-5 & $(56)$ \\
\hline $\begin{array}{l}\text { Pepper - } \\
\text { Phytophthora } \\
\text { capsici }\end{array}$ & Foliar spray & PR-2, PR-5 & PR-2, PR-5 & $(21)$ \\
\hline $\begin{array}{l}\text { Sunflower - } \\
\text { Peronospora } \\
\text { halstedii }\end{array}$ & Root drench & None & Not tested & $\begin{array}{l}\text { (Y. Cohen, } \\
\text { unpublished }\end{array}$ \\
\hline
\end{tabular}

protein accumulation. Interestingly, BABA induced PR1 mRNA accumulation in saltor heat-treated Arabidopsis (22). It seems that solanaceous plants such as tomato, pepper, and tobacco may respond to BABA by accumulating PR proteins without inoculation, whereas crucifers (Arabidopsis, cauliflower) require a challenge inoculation to promote PR protein accumulation.

Jeun (23) observed both local and systemic accumulation of P14 and AP29 PR proteins in BABA-treated but noninoculated tomato plants. These proteins also accumulated in $P$. infestans haustoria invading BABA-treated tomato leaves, as well as in cell-wall appositions (papillae). He concluded that PR proteins may directly act on the fungus.

Phytoalexins. BABA-induced phytoalexin accumulation was also dependent on the pathosystem used. Our studies showed no phytoalexins in leaves or stems of nonchallenged tobacco after foliar application or stem injection with BABA, respectively (5). Hwang et al. (21) showed a very low level of capsidiol in pepper stems treated with BABA, but upon inoculation with Phytophthora capsici, a strong accumulation of this phytoalexin occurred. Siegrist and Muhlenbeck (53) and Siegrist et al. (54) showed that preincubation of parsley cells in BABA rendered them more sensitive to an elicitor derived from Phytophthora soja, so as to secrete 15 times more furamocumarin phytoalexins compared with control cells. Raviv (47) observed enhanced autofluorescence of tomato leaf disks $20 \mathrm{~h}$ after inoculation with $P$. infestans sporangia mixed with BABA. Chamsai et al. (3) found phenolic accumulation in the root of BABA-treated tomato plants.

It seems that BABA potentiates some plant tissues not only to produce more PR proteins upon inoculation but also to produce more phytoalexins. Such observations support the hypothesis that plant and pathogen-specific defense mechanisms induced by BABA may depend not only on the plant species but also on the elicitor(s) released by the specific pathogen.

Hypersensitive reaction and reactive oxygen species. BABA induced the formation of small necrotic spots in tobacco $(5,55)$, tomato (6), Arabidopsis (66), and cauliflower (56) 1 or 2 days after foliar application. No leaf lesions were formed when BABA was applied to the roots. SAR developed following both application methods. Studying resistance against TMV in tobacco, Siegrist et al. (55) observed that BABA-induced cell death in lesions was associated with rapid generation of the reactive oxygen species (ROS) superoxide and $\mathrm{H}_{2} \mathrm{O}_{2}$ and, consequently, lipid peroxidation. They suggested that BABA applied as a foliar spray triggers primary processes resembling those initiated by microbes during the hypersensitive reaction (HR). BABA-mediated conditioning of plant 
tissue to respond in a resistant manner to the pathogen was found in tomato leaves. Leaves treated with water or BABA and then infiltrated with motile zoospores of $P$. infestans produced normal, sporulating lesions or HR, respectively. However, when infiltrated with dead zoospores of $P$. infestans, water-treated leaves showed no symptoms, while those treated with BABA developed a strong HR. These data suggest that BABA primes plant tissue to recognize a pathogen, or its components, in an incompatible manner.

Lee et al. (32) showed that BABA did not inhibit penetration of Phytophthora capsici into pepper stem tissue but severely suppressed hyphal growth and sporulation. BABA induced the formation of electrondense cell wall appositions that encased the haustoria, thus avoiding ingress of the pathogen into inner tissues, in a similar manner to a resistant host producing incompatible interaction with Phytophthora capsici. Also, in both BABA-treated and incompatible interactions, hyphal mitochondria degenerated. Mitochondrial degeneration was also observed in $P$. infestans infecting BABA-treated tomato leaves (47).

\section{Signaling Pathways}

BABA applied as a foliar spray induced SA accumulation in tobacco (55), tomato (25), and pepper (21). Does this imply that BABA operates via the SA-signaling pathway?

Tobacco plants expressing the salicylicacid-hydroxylase gene $(N a h G)$, and therefore impaired in the salicylic acid signaling pathway of SAR (26), were protected by BABA against Peronospora tabacina (41) (Figs. 3 and 4) but not against TMV (55), indicating pathogen-specific mechanisms of defense. Ethylene also was not involved in BABA-mediated resistance against Peronospora tabacina (5) in tobacco. Using a series of Arabidopsis mutants, Zimmerli et al. (66) showed that BABA was fully protective against Peronospora parasitica in mutants impaired in the salicylic acid, jasmonic acid, or ethylene signaling pathways. However, when challenged with Pseudomonas syringe pv. tomato, BABA was not protective in mutants impaired in the SAR transduction pathway (NahG, npr1), implying that different defense mechanisms were operating against oomycetes versus bacteria $(22,66)$. Further studies by Zimmerli et al. (67) showed that the necrotrophic fungal pathogen $B$. cinerea could be controlled by treating Arabidopsis with BABA. Protection was still effective in mutants impaired in the jasmonic acid and ethylene pathways but not in mutants impaired in the salicylic acid pathway (NahG, npr-1), indicating that SA and NPR-1 gene (synonym NIM-1) are involved in BABAmediated protection of Arabidopsis against B. cinerea. Taken together, BABA protects against oomycetes independent of the SA pathway but requires the SA pathway to protect against TMV, bacteria, and a necrotrophic fungus. BABA, therefore, differs from other plant activators (INA, BTH) which operate with all pathogens via the SAR pathway of PR-proteins $(16,26,35$, 40,57). Interestingly, BABA (1 mM) failed to inhibit the BTH-binding protein-kinase of tobacco (C. Pillonel, personal communication). This enzyme, which was suggested to regulate the NIM-1 (=NPR-1) protein, is inhibited by INA and therefore was considered to be its target site (46).

\section{Physiological and Developmental Effects}

Amino acids. BABA is a synthetic, nonprotein amino acid that may perturbate amino acid metabolism in plants. Assays were conducted to reveal the effect of BABA, as well as its two noninducing isomers, on the content of amino acids in tomato plants. Tomato plants were sprayed with AABA, BABA, GABA, or water, and leaves were analyzed 2 days later for amino acid content. GABA caused no major changes in amino acid content compared with water-treated plants. AABA increased $(\geq 30 \%)$ the content of 3 amino acids, whereas BABA increased $(\geq 30 \%)$ the content of 12 amino acids.

Photosynthesis. Incorporation of ${ }^{14} \mathrm{CO}_{2}$ into tomato plants was measured after a pretreatment with AABA, BABA, or GABA. Incorporation of ${ }^{14} \mathrm{CO}_{2}$ into ethanol-soluble or -insoluble sugars was not affected by BABA or GABA but was slightly reduced in AABA-treated plants, probably due to its minor toxicity to tomato plants, suggesting that BABA does not impair photosynthesis.

Flowering and seed production. Jakab et al. (22) observed female sterility in BABA-treated Arabidopsis plants resulting from over-production of callose in ovules. They confirmed the role of callose in female sterility by using 2-deoxy-D-glucose (DDG), an inhibitor of callose synthesis. DDG reversed the sterility and increased siliques length and seed production in a dose-dependent manner. The authors also selected 15 putative BABA-insensitive mutants (bai), which developed siliques (and seed) even after repeated BABA treatments. Of the 15 mutants, 7 allowed growth of Peronospora parasitica after BABA application (22), suggesting their loss of callose synthesis ability coincided with loss of inducing resistance against downy mildew. Nevertheless, the fact that 8 bai mutants were still resistant-responsive to BABA confirms that other mechanisms beside callose formation in papillae (66) operate during resistance.

Shailasree et al. (52) treated seeds of pearl millet with BABA and observed a high level of induced resistance against downy mildew. They followed the growth and the reproduction of the BABA-protected plants for 30 and 60 days, respec- tively. At 30 days, BABA-treated plants were taller $(34 \%)$, had larger leaf area (34\%) and heavier dry weight $(53 \%)$ than the control plants. Such plants developed four tillers per plant compared with only two in the control plants. Reproductive growth analysis at 60 days showed that BABA-treated plants had twice as many tillers per plant as the control plants, seed heads 50\% longer and 33\% thicker, and seed weight $61 \%$ higher.

\section{Reversibility of BABA-Mediated Resistance}

The finding that BABA enhanced the accumulation of protein amino acids in tomato plants raised the possibility that such accumulation may lead to resistance. Ovadia (41), therefore, supplied amino acids to tomato or grape leaf disks and measured their response to $P$. infestans and Plasmopara viticola, respectively. Excessive supply of protein amino acids failed to mimic the effect of BABA on disease development, that is, none of the 20 amino acids (up to $20 \mathrm{mM}$ ) suppressed $P$. infestans or Plasmopara viticola development. Surprisingly, coapplication of any of the 20 amino acids together with BABA compromised, to various extents, the resistance induced by BABA against $P$. infestans in tomato and Plasmopara viticola in grapes. The most effective compromising amino acids were L-proline and GABA (43). This compromising effect of BABAmediated induced resistance was also observed in whole tomato plants treated with a mixture BABA + L-proline (41).

L-Proline and GABA share the proline transporter LeProT1 to penetrate into tomato pollen cells (51). Our assumption was that BABA, due to its chemical similarity to GABA, also uses this transporter and that reversibility of resistance may result from inhibition of BABA uptake. Indeed, addition of other aminobutyrates or Lproline reduced the uptake of ${ }^{14} \mathrm{C}$-BABA into leaf disks. Inhibition of uptake was positively correlated with disease development, namely chemicals that inhibit uptake of $\mathrm{BABA}$ reduced its inducing activity against disease. Application of L-proline to leaf disks after being treated with BABA did not compromise SAR, probably due to lack of competition during uptake.

\section{Structure-Activity Relationship}

Aminobutyric acids do not occur in natural proteins (49), but may be found in plants. GABA is widely distributed in plants (especially seeds) and is used as an $\mathrm{N}$ source during germination and protectant against salinity (27). BABA has been reported in root exudates of tomato roots and in Migheli Type $\mathrm{C}$ carbonaceous chondrite $(15,17)$. Chondria arumata is reported to contain 3-amino glutaric acid (49).

The resistance-inducing activity of aminobutrates depends not only on the specific 
structure of the molecule but also on the host-parasite system used. MacLennan et al. (34) reported on high activity of 2-aminoisobutyric acid and lower activity of D2-aminobutyric acid against apple scab. They found no activity with L-2-aminobutyric acid, BABA, or DL-3-aminoisobutyric acid. Conversely, Papavizas and Davey (45) showed no activity of 2-aminoisobutyric acid against Aphanomyces euteiches in peas. They obtained high activity with DL-2-aminobutyric acid and with longer 2amino molecules having five (DL-2-aminovaleric), six (DL-2-amino caproic), or eight (DL-2-amino caprylic) carbon atoms, as well as with BABA, DL-threo methyl-aspartic acid, and DL-0-methylserine. Our studies revealed partial or no activity of the above (except BABA) molecules in tomato against $P$. infestans (6), in tobacco against Peronospora tabacina (5), or in grapes against Plasmopara viticola (14). In these three pathosystems, as well as in a number of others, BABA or R-BABA was the most effective molecule $(5,7,14,21,22,36,41,42$, 44,47,55,56,58,59,66). Replacing the amino group in BABA with a hydroxyl group abolished the activity of the molecule.

Of the two enantiomers of BABA, the $(R)$ enantiomer was more active than the $(S)$ enantiomer in eliciting SAR in numerous plants $(5,7,14)$ including Arabidopsis against Peronospora parasitica (Y. Cohen, unpublished).

Metal salts of BABA were almost as effective as $\mathrm{BABA}$, but acid salts were less effective. The oxalic acid salt was exceptional in showing high activity (10).

\section{Epilogue}

BABA, a simple, nonprotein amino acid induces resistance against a large number of plant parasites. It operates via a variety of defense mechanisms, including physical barriers and biochemical changes leading to resistance. Initial studies indicate that BABA may effectively control plant disease in the greenhouse and the field. Due also to its synergistic interaction with fungicides or plant activators, it seems likely that BABA may successfully be incorporated in plant disease management under field conditions. Toxicological data as well as biodegradation studies are still required for registration.

\section{Acknowledgments}

I thank Sandoz Agro Ltd., Basel, and Makhteshim Ltd., Israel, and the following people for their assistance in generating some of the data presented: Alona Ovadia, A. Baider, and D. Gotlib of Bar-Ilan University; and Stefan Blarer (for supplying derivatives of BABA) and Regina Schallberger-Diethlm (for amino acid analyses) of Sandoz Agro Ltd., Basel.

\section{Literature Cited}

1. Bieleski, R. L., and Turner, N. A. 1996. Separation and estimation of amino acids in crude plant extracts by thin-layer electrophoresis and chromatography. Anal. Biochem. 17:278293.

2. Bush, D. R. 1999. Amino acid transport. Pages 305-318 in: Plant Amino Acids, Biochemistry and Biotechnology. B. K. Singh, ed. Marcel Dekker, Inc., New York.

3. Chamsai, J., Buchenauer, H., Orober, M., and Siegrist, J. 1998. DL-3-aminobutyric acid induces localized cell death, salicylic acid, PR proteins and resistance in tomato and tobacco. International Workshop on Pathogenesis-Related Proteins in Plants Signaling Pathways and Biological Activities, 5th. Aussois, France.

4. Chester, K. S. 1933. The problem of acquired physiological immunity in plants. Q. Rev. Biol. 8:275-324.

5. Cohen, Y. 1994. 3-Aminobutyric acid induces systemic resistance against Peronospora tabacina. Physiol. Mol. Plant Pathol. 44:273288.

6. Cohen, Y. 1994. Local and systemic control of Phytophthora infestans in tomato plants by DL-3-amino-n-butanoic acids. Phytopathology 84:55-59.

7. Cohen, Y. 1996. Induced resistance against fungal diseases by aminobutyric acids. Pages 461-466 in: Modern Fungicides and Antifungal Compounds. H. Lyr, P. E. Russel, and H. D. Sisler, eds. Intercept, Andover, UK.

8. Cohen, Y. 1998. Method to protect plants from fungal infection. U.S. Patent 5,830,919.

9. Cohen, Y. 1998. Synergistic fungicidal mixtures of selected amino acids. Israel Patent 123346 (pending).

10. Cohen, Y. 2000. Methods for protecting plants from fungal infection. U.S. Patent 6,075,051.

11. Cohen, Y. 2001. Synergistic mixtures of an amino acid. Israel Patent 123722.

12. Cohen, Y., and Gisi, U. 1994. Systemic translocation of ${ }^{14} \mathrm{C}$-DL-3-aminobutyric acid in tomato plants in relation to induced resistance against Phytophthora infestans. Physiol. Mol. Plant Pathol. 45:441-456.

13. Cohen, Y., Niderman, T., Mosinger, E., and Fluhr, R. 1994. $\beta$-aminobutyric acid induces the accumulation of pathogenesis-related proteins in tomato (Lycopersicon esculentum Mill.) and resistance to late blight infections caused by Phytophthora infestans. Plant Physiol. 104:59-66.

14. Cohen, Y., Reuveni, M., and Baider, A. 1999. Local and systemic activity of BABA (DL-3aminobutyric acid) against Plasmopara viticola in grapevines. Eur. J. Plant Pathol. 105:351-361.

15. Drey, C. N. C. 1985 . Beta and higher homologous amino acids. Pages 25-54 in: Chemistry and Biochemistry of Amino Acids. G. C. Barrett, ed. Chapman \& Hall, London.

16. Friedrich, L., Lawton, K., Ruess, W., Masner, P., Specker, N., Rella, M. G., Meier, B., Dincher, S., Staub, T., Uknes, S., Metraux, J. P., Kessmann, H., and Ryals, J. 1996. A benzothiadiazole derivative induces systemic acquired resistance in tobacco. Plant J. 10:6170 .

17. Gamliel, A., and Katan, J. 1992. Influence of seed and root exudates on fluorescent pseudomonads and fungi in solarized soil. Phytopathology 82:320-327.

18. Greyerbiehl, J. A., and Hammerschmidt, R. 1998. Induced resistance against Fusarium sambucinum in potato tuber tissue. (Abstr.) Phytopathology 88:S34.

19. Harnack, W., and Schwarz, J. 1966. Fungicidal compositions. UK Patent 1,048,507.

20. Hong, J. K., Hwang, B. K., and Kim, C. H. 1999. Induction of local and systemic resistance to Colletotrichum coccodes in pepper plants by DL-beta-amino- $n$-butyric acid. J. Phytopathol. 147:193-198.

21. Hwang, B. K., Sunwoo, J. Y., Kim, Y. J., and
Kim, B. S. 1997. Accumulation of beta-1,3glucanase and chitinase isoforms, and salicylic acid in the DL-beta-amino- $n$-butyric acid-induced resistance response of pepper stems to Phytophthora capsici. Physiol. Mol. Plant Pathol. 51:305-322.

22. Jakab, G., Cottier, V., Toquin, V., Rigoli, G., Zimmerli, L., Metraux, J.-P., and MauchMani, B. 2001. $\beta$-Aminobutyric acid-induced resistance in plants. Eur. J. Plant Pathol. 107:29-37.

23. Jeun, Y. C. 2000. Immunolocalization of PRprotein P14 in leaves of tomato plants exhibiting systemic acquired resistance against $P h y$ tophthora infestans induced by pretreatment with 3-aminobutryic acid and preinoculation with tobacco necrosis virus. Z. Pflanzenkrankh. Pflanzenschutz 107:352-367.

24. Jeun, Y. C., and Buchenauer, H. 2001. Infection structures and localization of the pathogenesis-related protein AP24 in leaves of tomato plants exhibiting systemic acquired resistance against Phytophthora infestans after pre-treatment with 3-aminobutyric acid or tobacco necrosis virus. J. Phytopathol. 149:141-153.

25. Jeun, Y. C., Siegrist, J., and Buchenauer, H. 2000. Biochemical and cytological studies on mechanisms of systemically induced resistance to Phytophthora infestans in tomato plants. J. Phytopathol. 148:129-140.

26. Kessmann, H., Staub, T., Hofmann, C., Maetzke, T., Herzog, J., Ward, E., Uknes, S., and Ryals, J. 1994. Induction of systemic acquired resistance in plants by chemicals. Annu. Rev. Phytopathol. 32:439-459.

27. Kinnersley, A. M., and Lin, F. 2000. Receptor modifiers indicate that 4-aminobutyric acid (GABA) is a potential modulator of ion transport in plants. Plant Growth Regul. 32:65-76.

28. Kuc, J. 1982. Induced immunity to plant disease. BioScience 32:854-860.

29. Kuc, J. 2001. Concepts and direction of induced systemic resistance in plants and its application. Eur. J. Plant Pathol. 107:7-12.

30. Kuc, J., Barnes, E., Daftsios, A., and Williams, E. B. 1959. The effect of amino acids on susceptibility of apple varieties to scab. Phytopathology 49:313-315.

31. Kuc, J., Williams, E. B., and Shay, J. R. 1957. Increase of resistance to apple scab following injection of host with phenylthiourea and Dphenylalanine. (Abstr.) Phytopathology 47:21-22.

32. Lee, Y. K., Hong, J. K., Hippe-Sanwald, S., and Hwang, B. K. 2000. Histological and ultrastructural comparisons of compatible, incompatible and DL-beta-amino- $n$-butyric acidinduced resistance responses of pepper stems to Phytophthora capsici. Physiol. Mol. Plant Pathol. 57:269-280.

33. Li, J. J., ZingenSell, I., and Buchenauer, H. 1996. Induction of resistance of cotton plants to Verticillium wilt and of tomato plants to Fusarium wilt by 3-aminobutyric acid and methyl jasmonate. Z. Pflanzenkrankh. Pflanzenschutz 103:288-299.

34. MacLennan, D. H., Kuc, J., and Williams, E. B. 1963. Chemotherapy of the apple scab disease with butyric acid derivatives. Phytopathology 53:1261-1266.

35. Metraux, J.-P., Ahl-Goy, P., Staub, T., Speich, J., Steinemann, A., Ryals, J., and Ward, E. 1991. Induced systemic resistance in cucumber in response to 2,6-dichloro-isonicotinic acid and pathogens. Pages 432-439 in: Advances in Molecular Genetics of PlantMicrobe Interactions. H. Hennecke and D. P. S. Verma, eds. Kluwer Academic Publishers, Dordrecht, Netherlands.

36. Oka, Y., and Cohen, Y. 2001. Induced resistance to cyst and root-knot nematodes in cereals by DL- $\beta$-amino- $n$-butyric acid. Eur. J 
Plant Pathol. 107:219-227.

37. Oka, Y., Cohen, Y., and Spiegel, Y. 1999. Local and systemic induced resistance to the root-knot nematode in tomato by DL- $\beta$-amino$n$-butyric acid. Phytopathology 89:1138-1143.

38. Oka, Y., Spiegel, Y., and Cohen, Y. 2001. Methods and compositions to protect crops against plant parasitic nematodes. U.S. Patent 6,201,023 B1.

39. Oort, A. J. P., and Van Andel, O. M. 1960. Aspects in chemotherapy. Mededel. Opz. Gent. 25:961-992.

40. Oostendorp, M., Kunz, W., Dietrich, B., and Staub, T. 2001. Induced disease resistance in plants by chemicals. Eur. J. Plant Pathol. 107:19-28.

41. Ovadia, A. 2001. Mode of action of 3-aminobutyric acid in systemic acquired resistance. Ph.D. thesis. Bar-Ilan University, Ramat-Gan, Israel.

42. Ovadia, A., Biton, R., and Cohen, Y. 2000. Induced resistance to downy mildew and Fusarium wilt in cucurbits. Proc. EUCARPIA Meeting Cucurbit Genetics Breeding, 7th. Acta Hortic. 510:55-59.

43. Ovadia, A., and Cohen, Y. 2000. Is induced resistance reversible? (Abstr.) Phytoparasitica 28:3.

44. Pajot, E., Le Corre, D., and Silue, D. 2001. Phytogard $^{(R)}$ and DL- $\beta$-aminobutyric acid (BABA) induce resistance in lettuce (Lactuca sativa $\mathrm{L}$.) against downy mildew (Bremia lactucae). Eur. J. Plant Pathol. 107:861-869.

45. Papavizas, G. C., and Davey, C. B. 1963. Effect of amino compounds and related substances lacking sulfur on Aphanomyces root rot of peas. Phytopathology 53:116-122.

46. Pillonel, C. 2001. Identification of a 2,6-dichloroisonicotinic-acid-sensitive protein kinase from tobacco by affinity chromatography on benzothiadiazole-sepharose and NIM-metal chelate adsorbent. Pest Manag. Sci. 57:676682.

47. Raviv, A. 1994. The mode of action of $\beta$ aminobutyric acid in inducing resistance in tomato plants against late blight. Ph.D. thesis. Bar-Ilan University, Ramat-Gan, Israel.

48. Reuveni, M., Zahavi, T., and Cohen, Y. 2001. Controlling downy mildew (Plasmopara viticola $)$ in field-grown grapevine with $\beta$-aminobutyric acid (BABA). Phytoparasitica 29:125133.

49. Rosenthal, G. A. 1982. Plant Nonprotein Amino and Imino Acids: Biological, Biochemical and Toxicological Properties. Academic Press, New York.

50. Ross, A. F. 1961. Systemic acquired resistance induced by localized virus infections in plants. Virology 14:340-358.

51. Schwacke, R., Grallath, S., Breitkreuz, K. E., Stransky, E., Stransky, H., Frommer, W. B., and Rentsch, D. 1999. LeProT1, a transporter for proline, glycine betaine, and gammaamino butyric acid in tomato pollen. Plant Cell 11:377-392.

52. Shailasree, S., Sarosh, B. R., Vasanthi, N. S., and Shetty, H. S. 2001. Seed treatment with $\beta$-aminobutyric acid protects Pennisetum glaucum systemically from Sclerospora graminicola. Pest Manag. Sci. 57:721-728.

53. Siegrist, J., and Muhlenbeck, S. 2001. Rapid testing of resistance-inducing agents with cultured parsley cells. Pages 381-387 in: Modern Fungicides and Antifungal Compounds II. Intercept Ltd., Andover, UK.

54. Siegrist, J., Muhlenbeck, S., and Buchenauer, H. 1998. Cultured parsley cells, a model system for the rapid testing of abiotic and natural substances as inducers of systemic acquired resistance. Physiol. Mol. Plant Pathol. 53:223-238.

55. Siegrist, J., Orober, M., and Buchenauer, H. 2000. Beta-aminobutyric acid-mediated enhancement of resistance in tobacco to tobacco mosaic virus depends on the accumulation of salicylic acid. Physiol. Mol. Plant Pathol. 56:95-106.

56. Silue, D., Pajot, E., and Cohen, Y. 2002. Induction of resistance to downy mildew (Peronospora parasitica) in cauliflower by DL- $\beta$-amino- $n$-butanoic acid (BABA). Plant Pathol. 51:97-102.

57. Sticher, L., Mauch-Mani, B., and Metraux, J P. 1997. Systemic acquired resistance. Annu. Rev. Phytopathol. 35:235-270.

58. Sunwoo, J. Y., Lee, Y. K., and Hwang, B. K. 1996. Induced resistance against Phytophthora capsici in pepper plants in response to DL- $\beta$-amino- $n$-butyric acid. Eur. J. Plant Pathol. 102:663-670.

59. Tosi, L., Luigetti, R., and Zazzerini, A. 1998. Induced resistance against Plasmopara helianthi in sunflower plants by DL- $\beta$-amino$n$-butyric acid. J. Phytopathol. 146:295-299.

60. Van Andel, O. M. 1958. Investigations on plant chemotherapy II. Influence of amino acids on the relation plant-pathogen. Tijdschr. Planteziekten 64:307-327.

61. Vogt, W., and Buchenauer, H. 1997. Enhancement of biological control by combination of antagonistic fluorescent Pseudomonas strains and resistance inducers against damping off and powdery mildew in cucumber. Z. Pflanzenkrankh. Pflanzenschutz 104:272-280.

62. Wadley, F. M. 1945. The evidence required to show synergistic action of insecticides and a short cut in analysis. U.S. Dep. Agric. ET Circ. 223.

63. Yun, H. K., Yi, S. Y., Yu, S. H., and Choi, D. 1999. Cloning of a pathogenesis-related protein-1 gene from Nicotiana glutinosa L. and its salicylic acid-independent induction by copper and beta-aminobutyric acid. J. Plant Physiol. 154:327-333.

64. Zhang, S., Martinez, N., Kokalis-Burelle, N., Tuzun, S., and Kloepper, J. W. 1998. Can PGRP induce systemic resistance against peanut leaf spot disease? (Abstr.) Phytopathology 88:S103.

65. Zhang, S., Reddy, M. S., Kokalis-Burelle, N., Wells, L. W., Nightengale, S. P., and Kloepper, J. W. 2001. Lack of induced systemic resistance in peanut to late leaf spot disease by plant growth-promoting rhizobacteria and chemical elicitors. Plant Dis. 85:879-884.

66. Zimmerli, L., Jakab, C., Metraux, J. P., and Mauch-Mani, B. 2000. Potentiation of pathogen-specific defense mechanisms in Arabi-

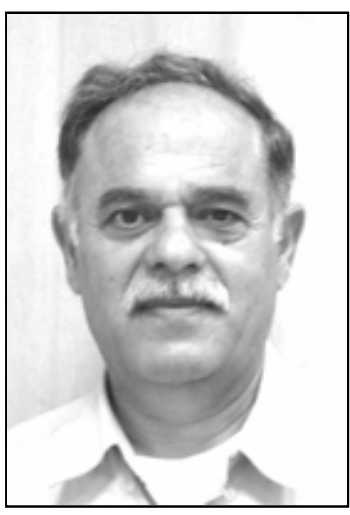

\section{Y. R. Cohen}

Dr. Cohen is a professor of plant pathology in the Faculty of Life Sciences at Bar-Ilan University in Ramat-Gan, Israel. He received his B.Sc. in 1963, M.Sc. in 1965, and Ph.D. in 1969. All degrees were from the Faculty of Agriculture of the Hebrew University of Jerusalem in Rehovot. In 1969 he was appointed as a lecturer, and in 1980 he was promoted to the rank of full professor at BIU. In 1996 he became a Fellow of APS, and in 1999 he was decorated with the Prize of Agriculture Research from the State of Israel. He became acquainted with systemic acquired resistance (SAR) during a sabbatical stay with Joseph Kuc at the University of Kentucky in 1980. His current interests include SAR activation with unsaturated fatty acids, fish oils, and fungal biomasses of the pharmaceutical industries, use of plant extracts for disease control, epidemiology of potato and tomato late blight, and genetics of Phytophthora infestans, horizontal resistance of tomato against late blight, genetic resistance of cucurbits against mildews, and cloning of resistance genes from melon. He has published about 170 scientific papers.

dopsis by $\beta$-aminobutyric acid. Proc. Nat. Acad. Sci. USA 97:12920-12925.

67. Zimmerli, L., Metraux, J. P., and MauchMani, B. 2001. $\beta$-aminobutyric acid-induced protection of Arabidopsis against the necrotrophic fungus Botrytis cinerea. Plant Physiol. 126:517-523. 
ERRATUM / Volume 86, Number 5, 2002

In the Feature article " $\beta$-Aminobutyric Acid-Induced Resistance Against Plant Pathogens" by Yigal R. Cohen, pages 448-457, the following figure captions should read:

Fig. 1. Protection of potato against Phytophthora infestans by a foliar spray with (left to right): water, DL- $\beta$-aminobutyric acid (BABA), DL- $\alpha$-aminobutyric acid (AABA), $\gamma$-aminobutyric acid (GABA) (2 $\mathrm{mg} / \mathrm{ml})$.

Fig. 2. Protection of tomato against Phytophthora infestans by cut-stem feeding with water (right) or DL- $\beta$-aminobutyric acid (BABA) (left, $1 \mathrm{mg} / \mathrm{ml}$ ).

Fig. 4. Protection of NahG tobacco against Peronospora tabacina. Clockwise from bottom right are plants treated with a foliar application of DL- $\beta$-aminobutyric acid (BABA) at 16, 31, 62, 125, 250, 500, 1,000 , and $2,000 \mu \mathrm{g} / \mathrm{ml}$.

Fig. 5. Control of Fusarium wilt of: A, watermelon (Fusarium oxysporum f. sp. niveum) and $\mathrm{B}$, muskmelon ( $F$. oxysporum $\mathrm{f}$. $\mathrm{sp}$. melonis) following a soil drench of DL- $\beta$-aminobutyric acid (BABA) at $20 \mathrm{mg} \mathrm{kg}^{-1}$ soil. Plants on left were drenched with water only.

In Table 6, page 454, the row with the ninth Plant - pathogen combination should read:

Plant - $\quad$ Mode BABA PR-proteins accumulation pathogen application Before challenge After challenge

Reference

Cauliflower Peronospora Foliar spray None

PR-2 